\title{
SELF-CONCEPT AND ACADEMIC PERFORMANCE
}

\author{
By: Liah Rosdiani Nasution ${ }^{1}$
}

\begin{abstract}
ABSTRAK
Artikel ini berusaha untuk melihat hubungan antara konsep diri siswa dan performa akademis siswa dan bagaimana hal itu mempengaruhi dan menentukan prestasi akademik siswa dengan menyelidiki tiga artikel penelitian yang melaporkan hubungan antara konsep diri siswa dan pertunjukan akademis. Artikel pertama oleh DeFreitas dan Rinn (2013) meneliti peran konsep diri dalam prestasi akademik dan penelitian kedua yang dilakukan oleh Zahra, Manzoor \& Yousuf (2010) membahas topik yang sangat mirip dengan tiga ranah konsep diri siswa. yang merupakan konsep diri akademik, fisik dan sosial menemukan bahwa konsep diri secara langsung mempengaruhi prestasi akademik siswa. Akhirnya, artikel jurnal ketiga yang dilakukan oleh Drysdale dan Milne (2004) mengeksplorasi perbedaan gender dalam konsep matematika dan verbal dan dampak yang mereka dapatkan terhadap prestasi akademik siswa juga yang pada dasarnya menemukan temuan serupa juga. Dengan pemikiran ini, perlu digarisbawahi bahwa walaupun ada beberapa variabel lain yang menentukan kinerja akademis siswa, data tersebut menunjukkan bahwa ini adalah tingkat konsep diri yang dimiliki seorang siswa yang memprediksi hasil selanjutnya dalam kinerja akademisnya. Semakin positifnya, semakin baik performa akademisnya, dan sebaliknya. Dari temuan ini, sangat penting bagi orang tua, guru, pembuat kebijakan, dan semua pihak yang terlibat dalam hal ini untuk menekankan perkembangannya pada siswa mereka dan orang-orang yang berkepentingan dengan metode yang tepat. Sebagai salah satu isu paling serius yang menyerang peserta didik saat ini, mungkin, memberikan perhatian khusus pada isu konsep diri yang rendah dapat membantu menjawab pertanyaan yang kita miliki tentang prestasi akademis siswa kita.
\end{abstract}

Keywords: Self-Concept, Academic Performance, Gender Differences.

\footnotetext{
${ }^{1}$ Liah Rosdiani Nasution is an Educational Psychology Lecturer of English Education Department in Tarbiyah and Teacher Training Faculty IAIN Padangsidimpuan.
} 


\section{DISCUSSION}

\section{A. Self- Concept}

In the realm of teaching and learning, it is popularly known to many people that self-concept plays a significant role in students' academic success. In addition, not only is it good academically but it is also good socially. Despite its great importance, however, a lot of people of interest such as parents, teachers and policy makers, for instance, do not really understand the meaning of self-concept and why it is such a big deal in the narratives of students' academic success. Before discussing the relationship between self-concept and academic achievement, it is important to first examine the definition of a self-concept.

DeFreitas and Rinn said that a "self-concept is an individual's evaluation of self that is based on his or her experiences and interpretations of those experiences". ${ }^{2}$ Similarly, Zahra et al defined self-concept as "The composite of ideas, feelings, and attitudes people have about themselves". ${ }^{3}$ This means that the definition of self- concept is pretty much the same across aspects of human lives; the perception one has about himself. This perception of self not only includes individual strengths but also weaknesses or even failures. Thus, self-concept is the basic concepts, personal opinion, thoughts, and consciousness about what, who and how one is in regards to how he sees himself.

This definition supports the two previous definitions mentioned earlier. Self-concept is a powerful factor that could motivates certain behaviors which eventually affect the way we perform on something. Franken even went to the

\footnotetext{
${ }^{2}$ De Freitass, S. C., and Rinn, A., Academic achievement in first generation college students: The role of academic self-concept, (Journal of the Scholarship of Teaching and Learning, 13, 2013), p. 57.

${ }^{3}$ Zahra, A. T., Manzoor, H. A., Yousuf, M. I., Relationship of Academic, Physical and Social SelfConcepts of Students with Their Academic Achievement, (Contemporary Issues in Education Research, 3, 2010), p. 73.
} 
extent of saying that self-concept is the foundation of every motivated actions that we do. "It is the self-concept that gives rise to possible selves, and it is possible selves that create the motivation for behavior. This supports the idea that one's paradigm or world view and one's relationship to that view provide the boundaries and circumstances within which we develop our vision about possibilities". 5

That being said, it is safe to suggest that self-concept is where it all started. Poor academic performance could be seriously affected by a low self-concept which manifested in the feeling of worthless, un-capable, unimportant and all the negative self-value. A great deal of research has also shown that self-concept directly influences academic performance. (Rady, Kabeer \& El-Nady, 2016; Laryea, Saani \& Dawson-Brew, 2014; Kumari \& Chamundeswari, 2013; Doodman, Zadeh, Changizi, 2017; Booth \& Gerard, 2011).

For teachers, helping students to develop self-concept in academic scope can be a very good starting point to go from before teaching them materials. In fact, it should probably be considered as everyone's duty, considering how influential it can be. It should also be embedded in the materials taught to ensure that the students can keep up the hard work in learning process. Understanding the importance of self-concept can be very useful to address the gap between low achieving students and high achieving students in a classroom setting.

A student who has negative beliefs about himself can be significantly lower in terms of academic achievement compared to a student who has strong and positive beliefs about himself. Therefore, it is safe to say that self-concept is one of

\footnotetext{
${ }^{4}$ Franken, R., Human Motivation (3rd ed.). Pacific Grove, (CA: Brooks/Cole Publishing Co, 1994), p. 98.

${ }^{5}$ Kumari, Archana., Chamundeswari, S., Self-Concept and Academic Achievement of Students at the Higher Secondary Level, (Journal of Sociological Research, 4, 2016), p. 106.
} 
the most determining factors in academic success. Thus, helping them with their self-concept problems might solve the puzzle of students' success in school.

\section{B. Academic Achievement}

As previously explained, academic achievement is one of the most common ways used in assessing students' level of mastery, understanding and excellence on the materials that have been taught in the classrooms. As a mainstream way, however, there are a lot of issues going on with the current method of evaluating students' academic performance. For one and among many others, the current method used in the investigation of students' standards of excellence mainly focuses on assessing what the students' physically know, often times disregarding what they feel and think which are of important part of the knowledge they gained as well.

Judging the students solely based on their scores, for instance, only shows that psychological factors which occupy a great involvement in the process of learning are greatly denied. Not only does it jeopardize the development of students' self-concepts, it also threatens the teachers' and students' interpersonal relationships which would eventually severe their academic performances and achievements. Theoretically speaking, this would further contradict the theoretical frameworks supporting the importance of the examination of environmental factors emphasized in Bronfrenbrenner's research in 1979 ecological theory and the socioemotional factors underlined in Vigotsky's finding in 1962 socio-cultural theory, and Bandura's study in 1977 social learning theory which basically suggest that there are psychological variables influencing achievement. 


\section{How are self-concept and academic performance related?}

In an attempt to deeper understand the relationship between self-concept and academic success, it is necessary to know that self-concept is hierarchical and multifaceted. As a hierarchical concept, this means that a self-concept has levels that can differentiate self-concepts. Similarly, as something multifaceted, this means that a self-concept has more than one dimension to look at. According to the self-concept model proposed by Shavelson, Hubner, and Stanton,

There are three dimensions used as a foundation of self-concept theory; general self-concept, academic self-concept, and non- academic selfconcept. The academic factor includes verbal ability, social science ability, science ability, and math ability factors. Non-academic self-concept revolves around social aspects such as friendship and appointment factors. ${ }^{6}$

The finding of the first journal article conducted by DeFreitas and Rinn suggests that high verbal and math self- concept is closely related to higher academic performances. ${ }^{7}$ While Zahra et al. explained that physical and social selfconcept are not related to academic performance, strong verbal and math selfconcepts, however, show a significant cause and effect relationship with academic performance. ${ }^{8}$ These two journal articles findings, in addition to other similar findings from different research, confirm that academic self-concept is a significantly important factor in academic success. These studies prove that a positive self-concept in academic setting leads to a better academic performance.

\footnotetext{
${ }^{6}$ Shavelson, R. J., J. J. Hubner, and G. C. Stanton, Validation of Construct Interpretations, (Review of Educational Research. 46, 1976), p. 407-441.

${ }^{7}$ DeFreitas and Rinn, Op. Cit., p. 59.

${ }^{8}$ Zahra, A. T., Manzoor, H. A., Yousuf, M. I., Op. Cit., p. 75.
} 


\section{Exploring Critical Factors affecting Self-Concept}

Developing a positive self- concept means developing a good sense of self that is relatively adaptive. It is important to know the variables that could potentially affects a good and bad self-concept. Bandura says that social cognitive learning theory suggests that learning is a result of some interacting variables; behavioral, personal and environmental variables. ${ }^{9}$ The behavioral factor is the reaction made by an individual when he is given a stimulus. Personal factor is the self- belief one has in general.

These two factors, personal and behavioral, are considered internal, however. The other factor is the environmental factor which is considered external because it refers to the influences an individual gets from outside. This could be in the form of social comparison, group association, or assumed roles. The environmental condition surrounding the individuals has a significant influence on the pattern of social learning. A student might think that smoking is socially acceptable his family members have been doing it since he was little, for instance.

Contrary to popular beliefs that internal factor has nothing to do with the environmental factor, the theory suggests that these two variables are interconnected and that both internal and external factors are equally significant in the development of one's self-concept. In fact, the theory even suggests that these factors are interacting which also indicates that self- concept is not stable. However, Kohut suggests a quite different opinion about self which, according to him, is

\footnotetext{
${ }^{9}$ Bandura, A., Social Learning Theory, (Englewood Cliffs, NJ: Prentice Hall, 1977), p. 99.
} 
stable. ${ }^{10}$ Although they are different from each other, these perspectives agree on the convention that a self-concept is the result of various personal experiences and accomplishments throughout the life span and that various life experiences have a huge impact on the development of concept of self. These experiences could be used to develop or improve students' self-concepts.

\section{E. Self-concept, Stereotype Thread and Academic Achievement}

In Indonesia, gender stereotype in education nowadays is not very obvious. However, the stereotype thread still prevails as shown in the selection of specialization at vocational schools and universities. Social sciences seem to be generally dominated by female students and technical sciences by male students. ${ }^{11}$ Hypothetically speaking, there are some factors that might contribute to this issue, such as:

1. Indonesian socio-cultural system, religious beliefs and traditions

Although most people in Indonesia believe that education is important, males get more encouragement and support when it comes to educational decisions. Although this particular attitude has been dramatically changed in the past few decades, it is still quite common to hear or see that girls are not necessarily encouraged to continue their studies after high school because they soon will get married, especially in rural parts of Indonesia. It is especially even more controversial to continue one's study overseas if that one is a woman.

\footnotetext{
${ }^{10}$ Kohut, H., The Restoration of the Self, (Madison, CT: International Universities Press, Inc, 1977), p. 157.

${ }^{11}$ M.Y. Nasution, Personal Communication, (April 27, 2016), p. 77.
} 
2. Early marriage

This is a serious issue that has drawn special attention from a lot of parties. In most provinces of Indonesia, twenty to twenty-five years old are considered to be the perfect time to get married. Once a girl exceeds this age limit, she will be considered to be a left-off woman. This greatly impacts the percentage of female participation in education.

3. Educational Policy

The Indonesian government is now paying a serious attention in giving more and more scholarships for women to ensure gender equality in education. This could be seen form the numbers of scholarship grantees from various scholarship providers. However, in the early 90 s, with the total of 40 students in a class, there were usually less than 10 women in each class I attended. ${ }^{12}$

4. The myth surrounding the questions of women abilities to deal with numbers. Although those factors above might be responsible for gender stereotype in academic settings in Indonesia, I will be focusing on the myth that females are not good in science. There has been a lot of research conducted to examine the relationship between gender and academic performances. Skaalvik in 1994 and Mboya in 1989 both confirm that males are better in academic self-concept which results in a better academic performance. ${ }^{13}$

\footnotetext{
${ }^{12}$ Ibid.

${ }^{13}$ Drysdale, M. T. B and Milne, S., Gender Differences in Math and Verbal Self-Concept and the Impact on Academic Achievement, (Self-Concept and Achievement, 2004), p. 1-14.
} 
5. Doodman, Parvaneh., Zadeh, Mojgan Amirian., Changizi, Bahador, however, suggest the opposite of that finding. ${ }^{14}$

In a study conducted by Drysdale \& Milne, "The result finds no significant relationship between gender and academic achievement and the correlational analysis indicates that all examined levels of self-concept were positively correlated with academic achievement in both Math and English". ${ }^{15}$ This finding clearly goes in line with other findings by other researchers that males do not necessarily have significant dominance in academic performance over females. Drawing form this finding, it is important to understand that raising students' self-concepts should be done regardless of their genders.

\footnotetext{
${ }^{14}$ Doodman, Parvaneh., Zadeh, Mojgan Amirian., Changizi, Bahador, Study the Relationship between Self-Esteem and Academic Achievement among High School Students in Lamerd City, (International Journal of Scientific Study, 5, 2017), p. 221-226.

${ }^{15}$ Drysdale, M. T. B and Milne, S., Op. Cit., p. 12.
} 


\section{CONCLUSION}

The journal articles covered in this paper all indicate that self-concept is a prominent factor in determining students' academic performance and thus, academic success. In understanding the self-concept, it is very important to know that self concept is a variable that can be developed and improved by examining and modifying the factors influence the development of self-concept. This is where a teacher plays a key role in helping the students disseminate their self-concepts.

Furthermore, it is critical to understand that academic achievement is not affected by gender, instead, it depends on how one perceives the situations he experienced. Furthermore, it is research-proven that females are not necessarily better in verbal reasoning and males are not always better in numbers. This critical finding can be used to better examine the issue surrounding students' academic performances. 


\section{REFERENCES}

Abd El Aziz Rady, Hanan Ebrahim., Kabeer, Shabana., El-Nady, Mona T. (2017). Relationship between Academic Self-Concept and Students' Performance among School Age Children. American Journal of Nursing Science, 5, 2016, 295-302.

Bandura, A. (1977). Social learning theory. Englewood Cliffs, NJ: Prentice Hall.

Bronfenbrenner, U. (1979). The ecology of human development. Cambridge, MA: Harvard University Press.

Bruning, Schraw, \& Norby. (2011). Belief about self. In. Cognitive Psychology and Instruction. (5th Edition).

De Freitass, S. C., \& Rinn, A. (2013). Academic achievement in first generation college students: The role of academic self-concept. Journal of the Scholarship of Teaching and Learning, 13,57-67.

Doodman, Parvaneh., Zadeh, Mojgan Amirian., Changizi, Bahador. (2017). Study the Relationship between Self-Esteem and Academic Achievement among High School Students in Lamerd City. International Journal of Scientific Study, 5, 221-226.

Drysdale, M. T. B \& Milne, S. (2004). Gender Differences in Math and Verbal SelfConcept and the Impact on Academic Achievement. Self-Concept and Achievement, 1-14.

Franken, R. (1994). Human Motivation (3rd ed.). Pacific Grove, CA: Brooks/Cole Publishing Co.

Kohut, H. (1977). The restoration of the self. Madison, CT: International Universities Press, Inc.

Kumari, Archana., Chamundeswari, S. (2013). Self-concept and academic achievement of students at the higher secondary level. Journal of Sociological Research, 4, 105-113. 
Laryea, Jhon Ekow., Saani, Abdul-Jaleel., Dawson-Brew, Emma. (2014). Influence of students' self-concept on their academic performance in the Elmina Township. European Journal of Research and Reflection in Educational Sciences, 2, 1-10.

Mboya, M. (1989). The Relative Importance of Global Self-Concept and Self- Concept of Academic Ability in Predicting Academic Achievement. Adolescence, 93, 3945.

Powell, K.C. (2009). The Role of Concept of Self and Societal Expectations in Academic and Career Achievement. Journal of Adult Education, 38, 32-40.

Shavelson, R. J., J. J. Hubner, and G. C. Stanton. 1976. Validation of Construct Interpretations. Review of Educational Research. 46, 407-441.

Skaalvik, E. (1994). Attribution of perceived achievement in school in general and in math and verbal areas: Relations with academic self-concept and self- esteem. British Journal of Educational Psychology, 64, 133-143.

Vygotsky, L. (1962). Thought and language. Cambridge, MA: MIT Press.

Zahra, A. T., Manzoor, H. A., Yousuf, M. I. (2010). Relationship of Academic, Physical and Social Self-Concepts of Students with Their Academic Achievement. Contemporary Issues in Education Research,3, 73-78. 